\title{
Characterization of Aromatic Hydrocarbon Degrading Bacteria from Petroleum Contaminated Sites
}

\author{
Swarnakaran Hemalatha, Panchanathan Veeramanikandan \\ Department of Biotechnology, Vels University, Chennai, India. \\ Email: hemas81@gmail.com \\ Received November $18^{\text {th }}, 2010$; revised January $13^{\text {th }}$, 2011; accepted February $10^{\text {th }}, 2011$.
}

\begin{abstract}
Aromatic hydrocarbons such as benzene, hexane, toluene, naphthalene and xylene degrading bacteria such as Flavobacterium spp. 1 \& 2 and Pseudomonas spp. 1 \& 2 were isolated from petroleum contaminated soil samples. They were resistant to heavy metals such as lead, iron, zinc, cobalt and mercury. The optimum $\mathrm{pH}$ for hydrocarbon degradation by Flavobacterium spp. 1 was 9. Flavobacterium spp.2, Pseudomonas spp. 1 \& 2 have shown optimum pH 7 for their degradation. The optimum temperature for hydrocarbon degradation by Flavobacterium spp.1 \& 2 and Pseudomonas spp. 1 \& 2 were at $40^{\circ} \mathrm{C} \& 45^{\circ} \mathrm{C}$.
\end{abstract}

Keywords: Aromatic Hydrocarbon, Flavobacterium, Pseudomonas, Heavy Metals, Temperature

\section{Introduction}

Aromatic hydrocarbons are common environmental pollutants with toxic, genotoxic, mutagenic and carcinogenic properties [1]. They mainly occur in petroleum industry activities [2]. Oil spills because of pipeline breakages, tanks leakages or storage and transportation accidents can be considered as the most frequent causes of hydrocarbon release, included PAHs into soils [3]. BTEX compounds are components of gasoline and aviation fuels that are carcinogenic and neurotoxic to most organisms [4].

Bacteria play a major role in hydrocarbon degradation. The reason for petroleum biodegradation is the ability of microorganisms to utilize hydrocarbons to satisfy their cell growth and energy needs. Low molecular weight alkanes are degraded most rapidly whereas mixed cultures carry out more extensive biodegradation of petroleum through pure cultures $[5,6]$. Therefore, biodegradation using microorganisms is usually preferred. They play major role in PAHs removal from contaminated environments because of some advantages such as cost effectiveness and more complete cleanup [7].

Toluene degrading bacteria putida PaW1, P. putida F1, P. mendocina KRI, Burkholderia cepacia G4, B. cepacia and Ralstonia pickettii PKO1 were characterized [8]. The biodegradation of naphthalene has been well studied at the molecular level and thus it serves as one of the principal models for understanding the mechanisms of bacterial benzene ring metabolism. Isolates CMBLHC1CMBLHC8 have potential use to clean up the environment containing hydrocarbons such as salicylate, phenanthrene, SDS and naphthalene. Eight bacterial strains (CMBLHC1-CMBLHC8) were isolated from petrol pumps soil samples and their tolerance was also checked on other hydrocarbons such as $0.01 \mathrm{M}$ salicylate, $0.008 \mathrm{M}$ phenanthrene, $0.01 \mathrm{M}$ SDS [sodium dodecyl sulfate) and naphthalene vapours [9]. CMBLHC2 and CMBLHC6 show maximum tolerance up to $0.5 \mathrm{M}$ benzoic acid and CMBLHC2, CMBLHC4, CMBLHC7 showed maximum tolerance up to $0.5 \mathrm{M}$ salicylate. Optimum $\mathrm{pH}$ ranged from 6.0 to 7.0. The optimum temperature for all strains was $37^{\circ} \mathrm{C}$. Isolated bacteria have also shown resistance against heavy metals and antibiotics.

Twenty four bacteria capable of utilizing naphthalene as their sole source of carbon and energy for growth from three different soils in Nsukula, Nigeria were isolated and characterized [10]. The usage of petroleum hydrocarbon products has been increased. Therefore, the soil contamination with diesel and engine oil is becoming one of the major environmental problems. Various microbial species are effective degraders of hydrocarbons in natural environment. Microorganisms such as bacteria, fungi, 
yeast and microalgae can degrade petroleum hydrocarbons $[11,12]$.

Flavobacterium, Acnetobacterium and Pseudomonas isolates are capable of utilizing used engine oil as a carbon source. The potential of Flavobacterium, Acnetobacterium and Pseudomonas for oil bioremediation in situ and ex situ were demonstrated [13]. Three bacteria such as Pseudomonas sp, Flavobacterium sp and Rhodococcus sp were isolated and considered as efficient gasoline degrading bacteria. The optimal growth conditions of three bacteria including $\mathrm{pH}$, temperature and the concentration of gasoline were similar [14]. Bacterial and fungal species such as Pseudomonas, Bacillus, Micrococcus, Aspergillus, Rhizopus, Mucor and Penicillium degrade hydrocarbon from the oil spilled area [15].

As the usage of petroleum hydrocarbons products increased, soil contamination with diesel and engine oils has become one of the major environmental problems. Uncontrolled and catastrophic releases of petroleum pose ecological and environmental repercussions, as a lot of hydrocarbon components are toxic and persistent in terrestrial and aquatic environments. Several physicochemical methods of decontaminating the environment have been established and employed. Biological degradation, a safe, effective and an economic alternative method, is a process of decay initiated by biological agents, specifically in this case by microorganisms. Therefore the counter measure to remediate soils contaminated with oils is by bioremediation. Bioremediation provide an effective and efficient strategy to speed up the clean up process. Therefore, the present study deals with the isolation and characterization of aromatic hydrocarbons degrading bacteria from oil contaminated sites.

\section{Materials and Methods}

\subsection{Sample Collection}

About $5 \mathrm{~g}$ of soil samples were aseptically collected from different petroleum contaminated sites in and around Chennai City, Tamil Nadu, India. Immediately they were brought to the laboratory. All samples were placed in to sterile polythene bags and stored at $4^{\circ} \mathrm{C}$.

\subsection{Hydrocarbon Substrates}

Hydrocarbon substrates such as Toluene, Benzene, Hexane, Xylene and Naphthalene were selected for study.

\subsection{Isolation of Bacteria}

Bacteria were isolated from soil samples using an enrichment medium containing petrol. Petrol was added to the medium after autoclaving. $1.0 \mathrm{~g}$ of soil sample was inoculated into the medium and incubated at $170 \mathrm{rpm}$ at $30^{\circ} \mathrm{C}$ in an orbital shaker for one week. After one week,
$1.0 \mathrm{ml}$ of the sample was taken from each culture and transferred into fresh enrichment medium, followed by incubation as described above for one week. At the end of second week, the bacterial contents were serially diluted and $10^{-2}$ dilution was placed in Bushnell Haas medium containing $15.0 \mathrm{~g} / \mathrm{L}$ of pure agar. Inoculated plates were purified repeatedly by sub culturing. Pure culture was stored in nutrient agar slants and stored at $4^{\circ} \mathrm{C}$.

\subsection{Identification of Bacteria}

The bacteria isolated were identified based on physical characterization and the biochemical tests outlined in Bergey's Manual of determinative Bacteriology [16].

\subsection{Characterization of Hydrocarbon Degrading Bacteria}

\subsubsection{Effect of Aromatic Hydrocarbon}

A loopful of isolated bacteria was inoculated in a freshly prepared and autoclaved BH medium in presence of five different aromatic hydrocarbons such as Benzene, Hexane, Toluene, Naphthalene and Xylene, whose concentration is $0.02 \%$. After 24 hours of incubation at $30^{\circ} \mathrm{C}$, the utilization of the aromatic hydrocarbons as sole carbon source was assayed for O.D at $600 \mathrm{~nm}$ in U-V spectrophotometer at an interval of 30 minutes. The Bushnell Haas medium (BH) devoid of aromatic hydrocarbon served as control.

\subsubsection{Effect of $\mathrm{pH}$}

Enrichment BH medium with varying $\mathrm{pH}$ such as 5, 6, 7, 8, 9 were prepared and autoclaved. A loopful of isolated bacteria was inoculated into it. The utilization of suitable hydrocarbon at different $\mathrm{pH}$ was read at $600 \mathrm{~nm}$ in U-V spectrophotometer at an interval of 30 minutes. The medium devoid of hydrocarbons served as control.

\subsubsection{Effect of Temperature}

A loopful of isolated bacteria was inoculated in enrichment BH medium. It was maintained at different temperature such as $30^{\circ} \mathrm{C}-45^{\circ} \mathrm{C}$. The utilization of suitable hydrocarbon at different temperature was read at $600 \mathrm{~nm}$ in UV spectrophotometer at an interval of 30 minutes. The medium devoid of hydrocarbons served as control.

\subsection{Heavy Metal Tolerance Spectrum of Hydrocarbon Degrading Bacteria}

The tolerance of bacterial isolates to various heavy metals such as Cobalt (Cobalt Chloride), Iron (Ferrous Sulphate), Mercury (Mercury Sulphate), Zinc (Zinc Sulphate) and Lead (Lead acetate) was studied by inoculating loopful of overnight grown cultures on Nutrient agar plates amended with 1,3 and $5 \mathrm{mM}$ concentration of heavy metals and incubated at $37^{\circ} \mathrm{C}$. After 24 hours of incubation, the plates were observed for growth. Nutrient 
Agar plates without heavy metals served as control.

\subsection{Estimation of Protein in Hydrocarbon Degrading Bacteria}

To $1 \mathrm{ml}$ of the bacterial supernatant, $1 \mathrm{ml}$ of $20 \%$ TCA was added and kept for half hour incubation. It was then centrifuged at $8000 \mathrm{rpm}$ for 20 minutes. The pellet was washed with acetone twice and again centrifuged it. The supernatant was discarded and the pellet was dissolved in $0.2 \mathrm{~m}$ phosphate buffer. The sample was stored at $4^{\circ} \mathrm{C}$ for further study. Protein concentrations were determined by Lowry's method using BSA (bovine serum albumin) as standard.

\section{Results and Discussion}

Polycyclic aromatic hydrocarbons are ubiquitous contaminants of terrestrial ecosystems whose presence is attributable to a number of petrogenic and pyrogenic sources, which had increased since the end of the II world war. Environments contaminated with PAHs are considered hazardous to humans exposed to them. Therefore, removal of pollutants from the environment is essential. Varieties of physical, chemical and biological ways were adopted already. But bacterial bioremediation technique offers new possibilities to accelerate the pollution degradation because they are widely present in the environment itself.

In the present study, four bacterial isolates have been isolated from different petroleum contaminated soil samples by crowded plate technique. With reference to physical and biochemical tests as outlined in Bergey's manual of determinative bacteriology, the bacteria were identified as Flavobacterium species and Pseudomonas species (Table 1). Their potential to degrade PAH was studied. The isolate which have shown the highest Optical Density (OD) value in different hydrocarbon was considered as the suitable hydrocarbon source for their degradation. The presence of local soil microbial population adapted to hydrocarbons form the basis of microbial methods.

It is also believed that the isolated organisms should posses catabolic enzymes for the specific biodegradation in the presence of different PAHs. The catabolic pathways, which encode the different aromatic hydrocarbon degradation routes, are frequently located on plasmids. Although degradation genes can be located on either chromosome or plasmid. Phenanthrene degrading Pseudomonas from crude oil contaminated soil samples collected in a petroleum refining area were isolated and characterized [17]. They concluded that hydrocarbon degradation routes are frequently located on plasmid.

All the four isolates degraded benzene, toluene, hexane, xylene and naphthalene. Flavobacterium sp. 1 have utilised xylene as carbon source and the highest OD of 0.37 was recorded (Figure 1). Flavobacterium sp. 2 have utilized toluene as carbon source and the highest OD of 0.372 was recorded (Figure 2). Pseudomonas sp. 1 and Pseudomonas sp. 2 have shown good growth in Toluene containing medium and the highest OD of 0.314 was recorded for both the organisms (Figures 3 \& 4).

The suitable hydrocarbon alone is not sufficient for bioremediation of environmental pollutants. Other physical parameters such as $\mathrm{pH}$ and Temperature are also essential because physio-chemical influence cause the microbial degradation of hydrocarbon. The optimum $\mathrm{pH}$ and temperature for degradation by four isolates were determined. The isolate, which have shown the highest OD value in varying $\mathrm{pH}$, was considered as the suitable $\mathrm{pH}$ for their degradation and the results are represented in Figures 5-8. The optimum $\mathrm{pH}$ for Flavobacterium sp. 1 was recorded as $\mathrm{pH} 9$. It shows the maximum peak value of 0.292 (Figure 5). The optimum $\mathrm{pH}$ for the Flavobacterium sp. 2, Pseudomonas sp. 1 and Pseudomonas sp. 2 were recorded as $\mathrm{pH} 7$ (Figures 6, 7 \& 8). Moreover these isolates illustrate maximum peak value of 0.404 , 0.207 and 0.288 respectively.

The $\mathrm{pH}$ range that is most suitable for soil microorganism is below 6 and 8 , with an optimum $\mathrm{pH}$ of about seven for most species. The optimum $\mathrm{pH}$ for Flavobacterium sp. 2, Pseudomonas sp. 1 and Pseudomonas sp. 2 was 7 in the presence of the hydrocarbon, which supports the investigation done by [18] who studied the effects of aerobic bacterial mixtures $\mathrm{pH}$, temperature and carbon sources on polyaromatic hydrocarbons. The optimal conditions for PAH biodegradation were determined as $30^{\circ} \mathrm{C}$ and $\mathrm{pH}$ 7. The isolate, which have shown the highest OD value in varying temperature, was considered as the suitable temperature for their degradation. The optimum temperature for degradation by Flavobacterium sp. 1and 2 was at $40^{\circ} \mathrm{C}$. They have shown optimum OD value of $0.353 \& 0.464$ respectively (Figures $9 \&$ 10). The optimum temperature for degradation by Pseudomonas spp1 was also at $40^{\circ} \mathrm{C}$. They have shown optimum OD value of 0.304. (Figure 11). But Pseudomonas sp. 2 degraded maximum hydrocarbon at $45^{\circ} \mathrm{C}$ with $\mathrm{OD}$ of 0.345 . (Figure 12). The optimum petroleum degradation rate by aerobic bacteria occurs at temperature below 15 and $30^{\circ} \mathrm{C}$ [19]. Since the selected organism have shown their maximum degradation at $40^{\circ} \mathrm{C}$ and $45^{\circ} \mathrm{C}$, these organism can be used for bioremediation to be carried out in summer months. Increases in optimum temperature increases the solubility of hydrocarbons too.

The biodegradation of aliphatic and aromatic hydrocarbons at high temperatures were investigated [20]. The solubility of naphthalene is increased by a factor of approximately ten if the temperature is increased from 20 to 
$75^{\circ} \mathrm{C}$, which increases the availability of sparingly soluble hydrocarbons.

The heavy metal tolerance spectrum of Flavobacterium spp. 1, Flavobacterium spp. 2, Pseudomonas spp. 1 and Pseudomonas spp. 2 were studied and the results are presented in Table 2. All the four isolates were tolerant to iron, zinc and lead upto $5 \mathrm{mM}$ concentration. But they were sensitive to cobalt and mercury even at $1 \mathrm{mM}$ concentration. Being sensitive no growth was observed in their plates. These results revealed that the presence of heavy metals such as cobalt and mercury even in $1 \mathrm{mM}$ concentration was highly toxic to the bacteria isolated from oil contaminated sites and they will pose serious threat to their metabolism in the environment. But they have shown resistance towards iron, zinc and lead. This could be attributed due to the presence of plasmid in their genetic makeup. The transferable plasmid encodes resistance to various heavy metals [21]. The protein content of hydrocarbon degrading bacteria was determined. It has increased to a smaller extent after utilizing hydrocarbon as substrate. But Pseudomonas spp. 2 has showed decrease protein content than control sample. The protein content of hydrocarbon degrading bacteria has varied between 1.4 - $1.8 \mathrm{mg} / 100 \mathrm{ml}$ (Table 3).

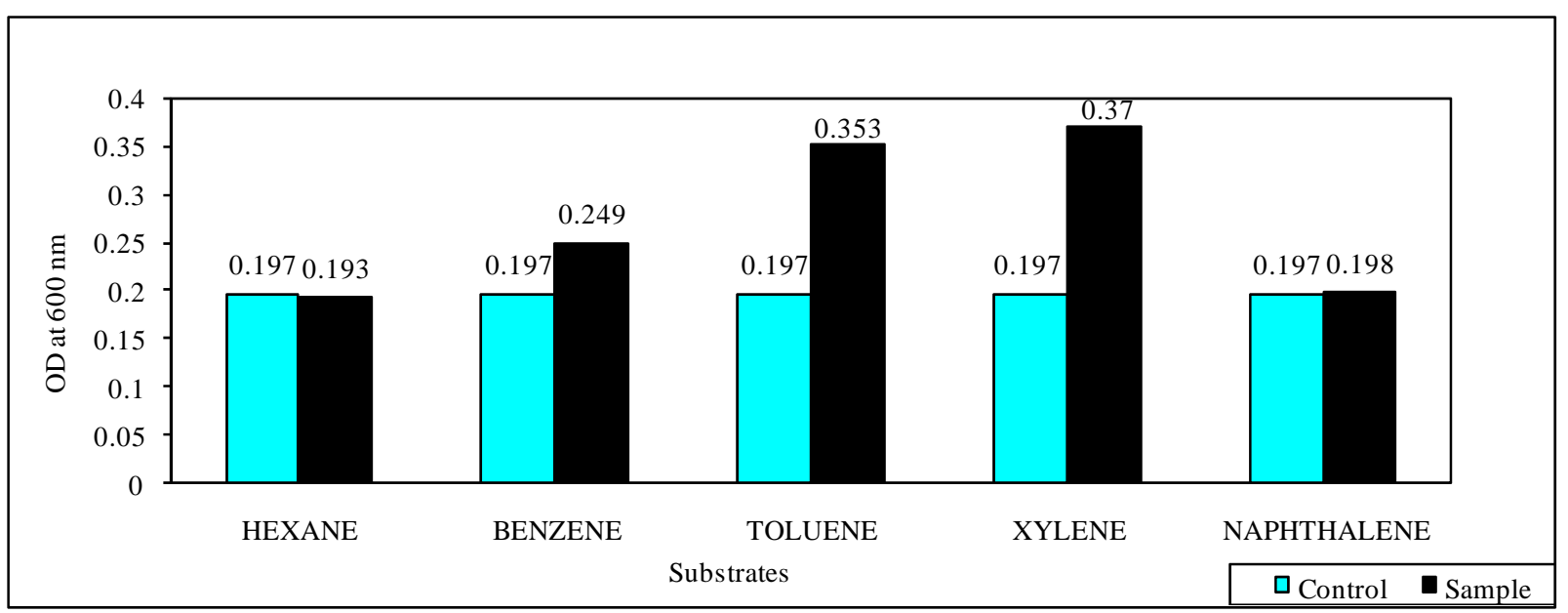

Figure 1. Average optical density obtained from Flavobacterium spp. 1 using different hydrocarbon.

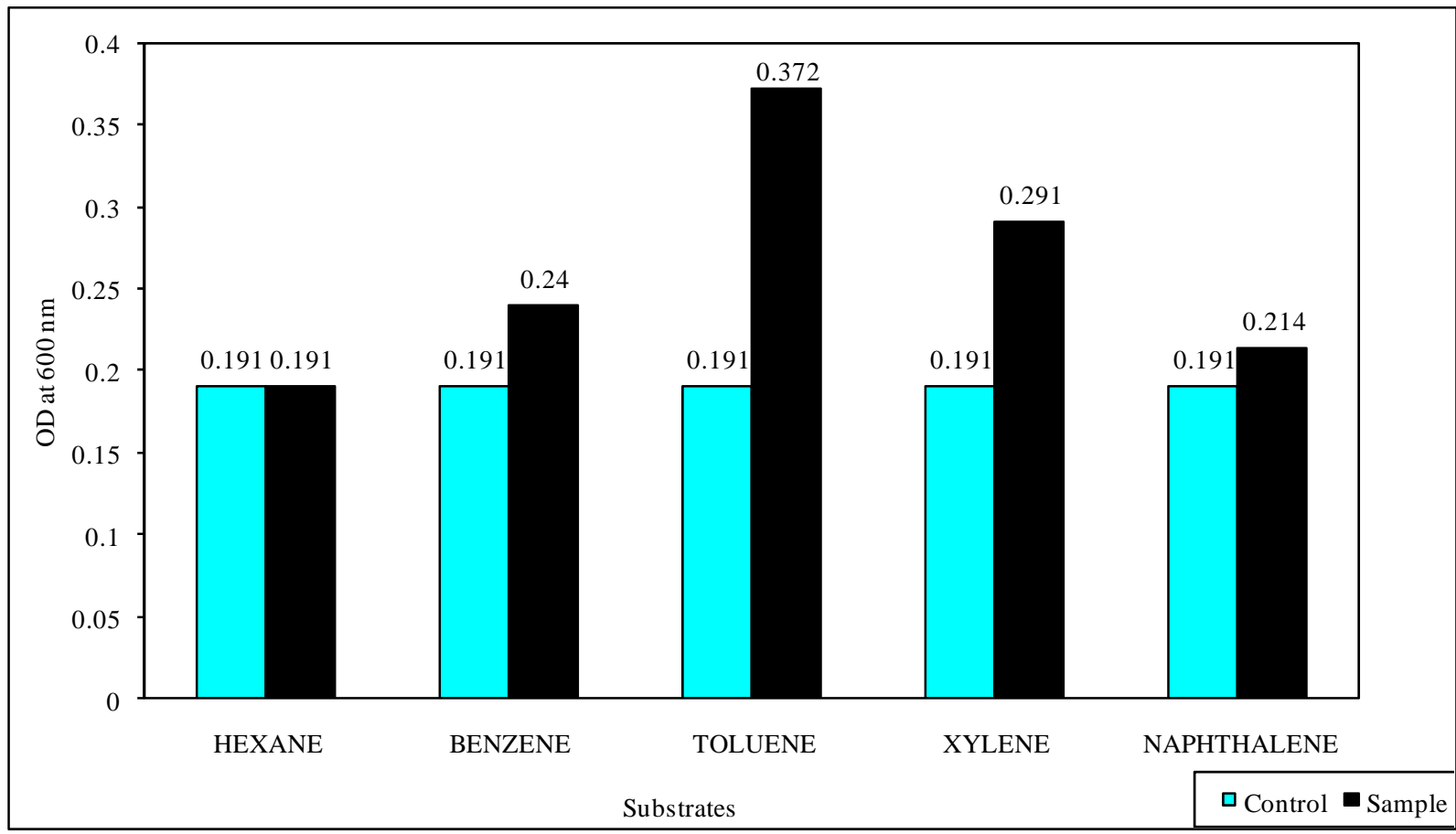

Figure 2. Average optical density obtained from Flavobacterium spp. 2 using different hydrocarbons. 


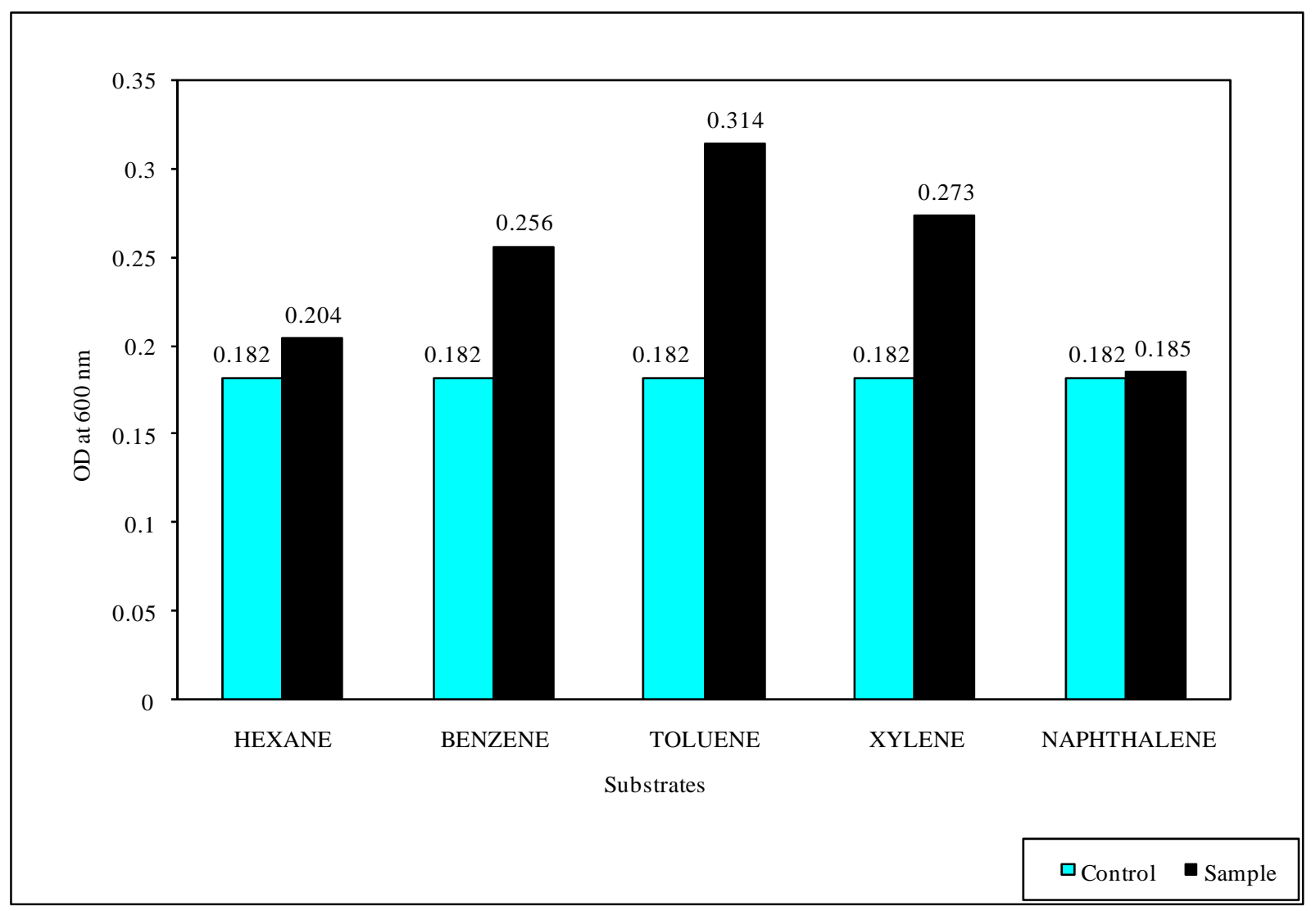

Figure 3. Average optical density obtained from Pseudomonas spp. 1 using different hydrocarbons.

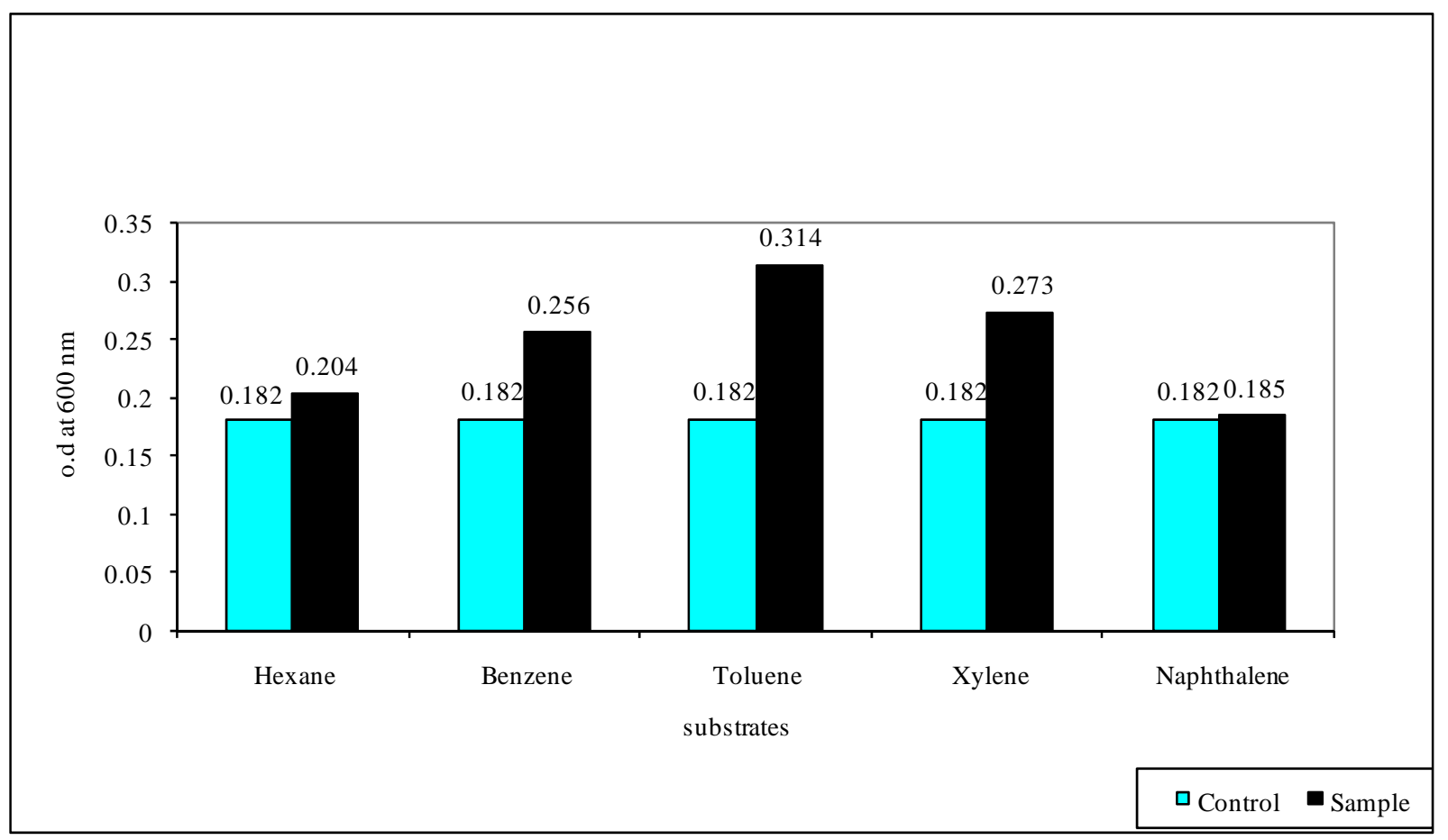

Figure 4. Average optical density obtained from Pseudomonas spp 2 using different hydrocarbons. 


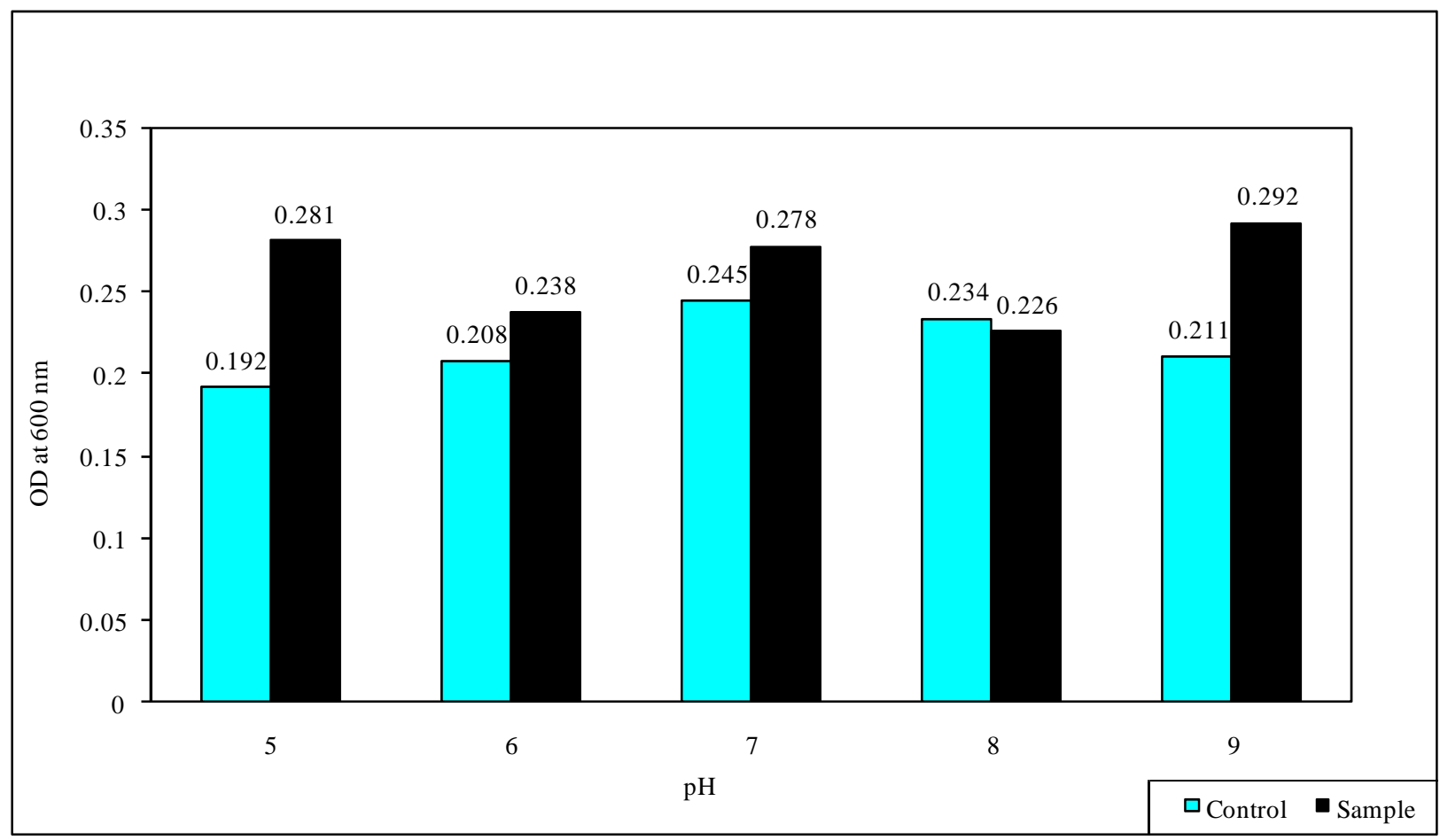

Figure 5. Average optical density of Flavobacterium spp. 1 grown in Bushnell haas medium using different pH.

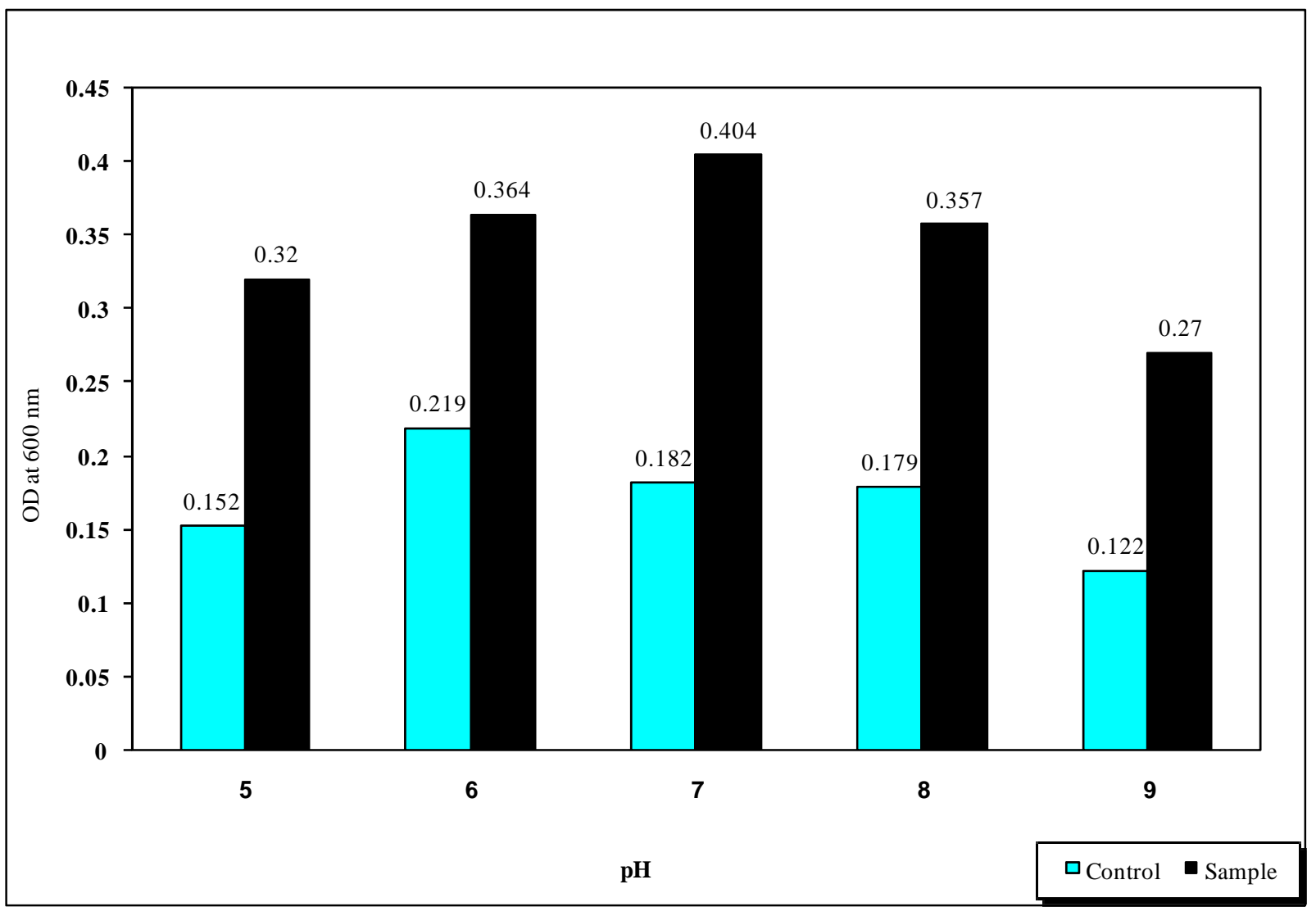

Figure 6. Average optical density of Flavobacterium spp. 2 grown in Bushnell haas medium using different pH. 


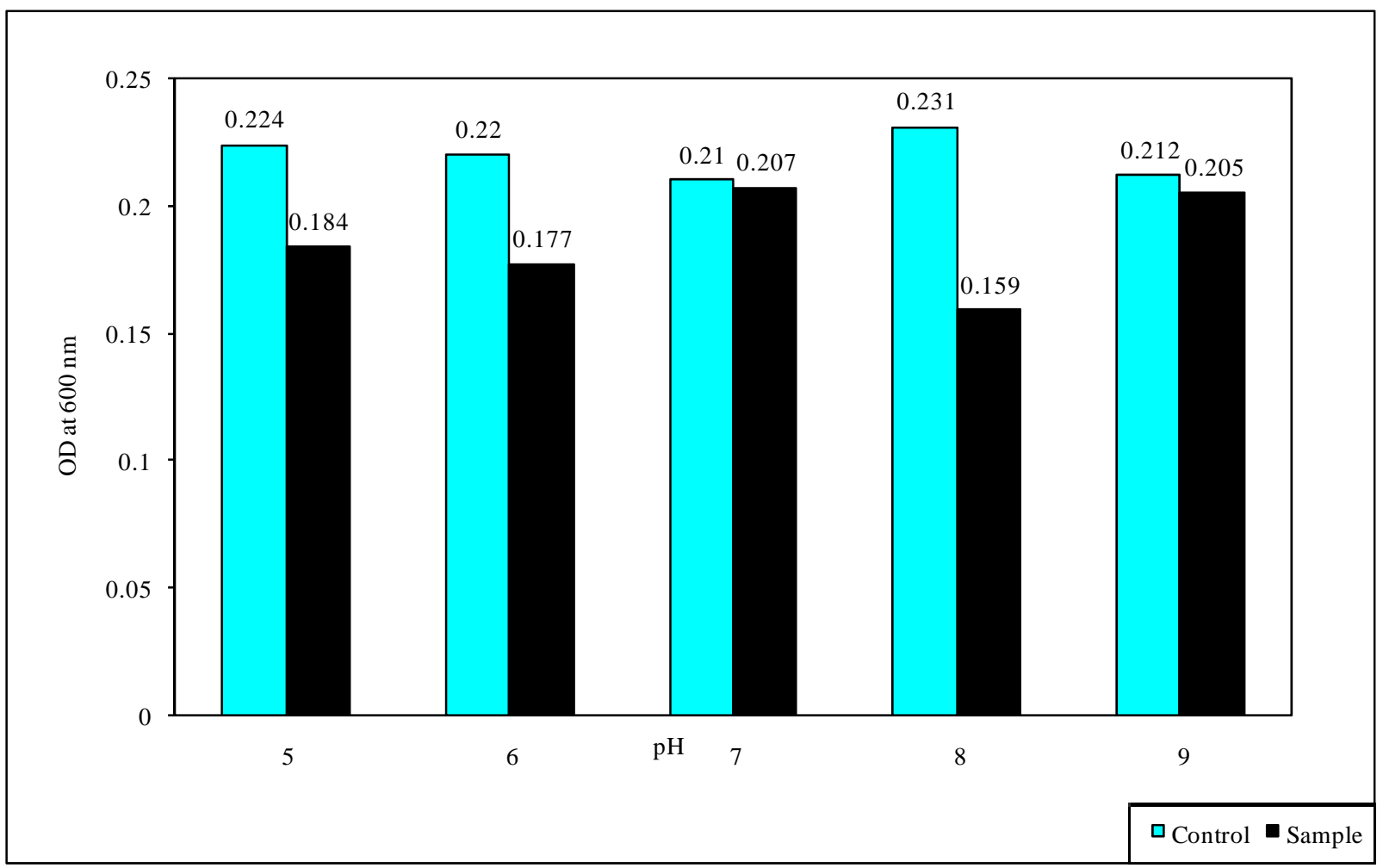

Figure 7. Average optical density of Pseudomonas spp. 1 grown in Bushnell haas medium using different pH.

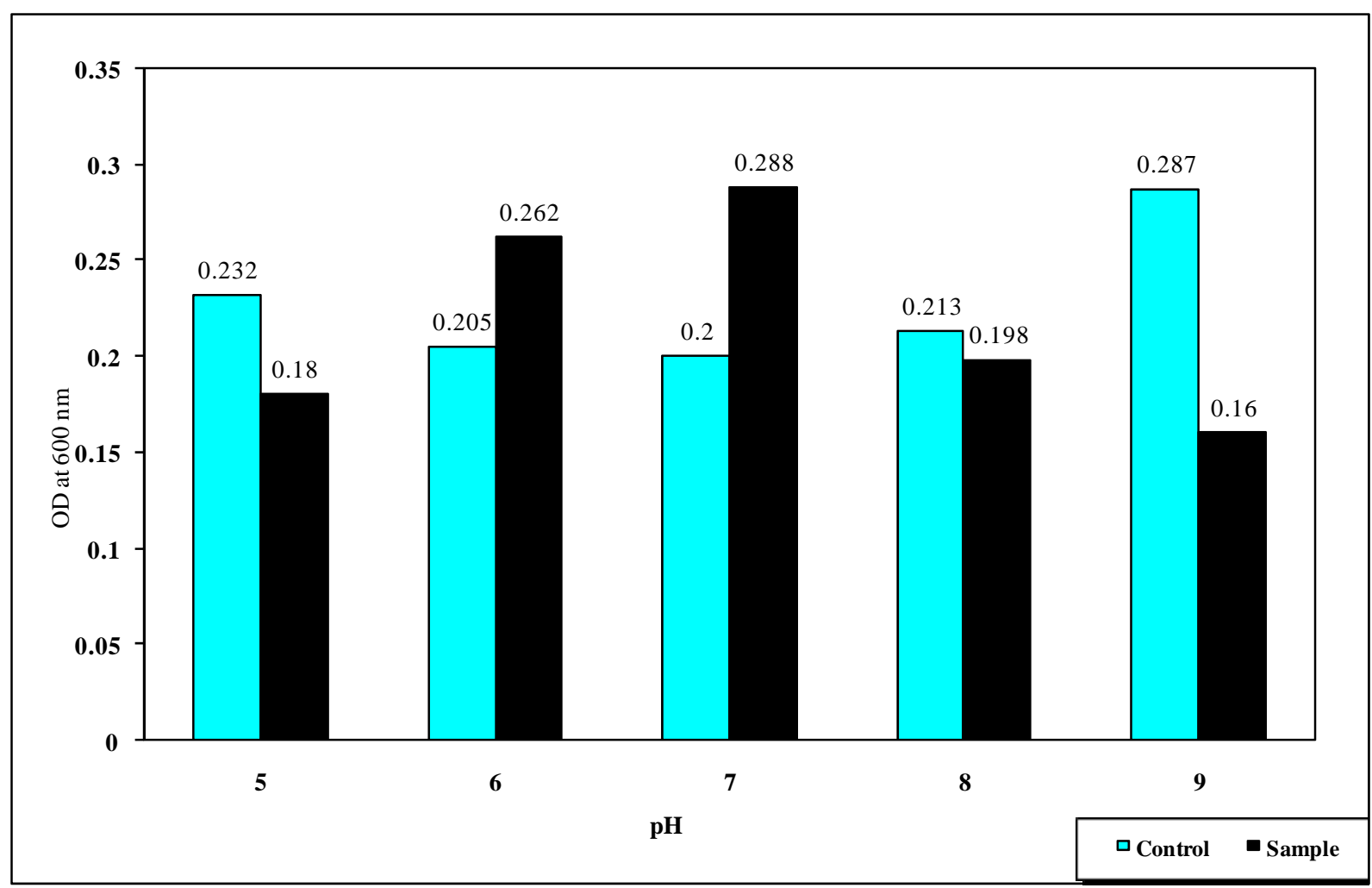

Figure 8. Average optical density of Pseudomonas spp. 2 grown in Bushnell haas medium using different pH. 


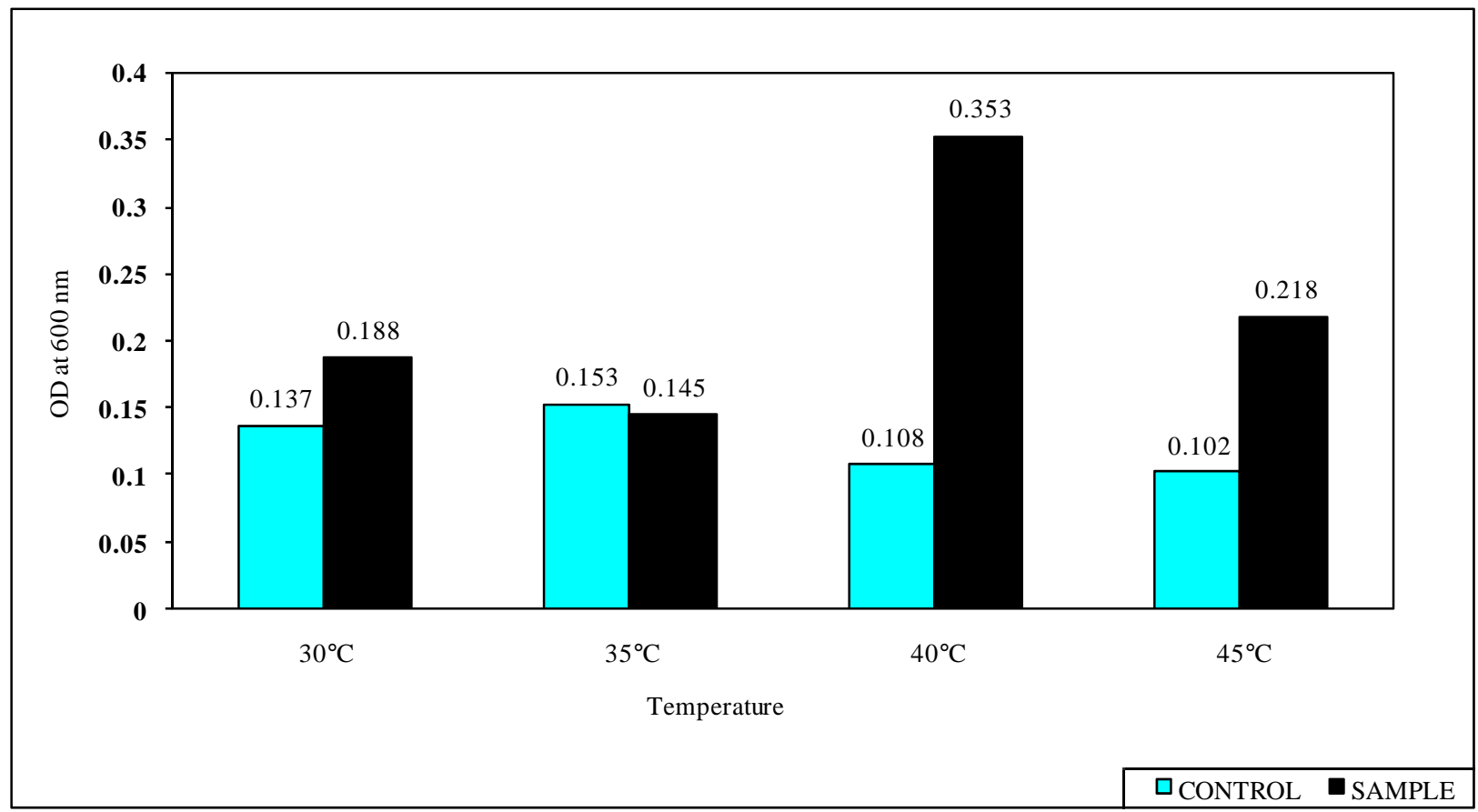

Figure 9. Average optical density of Flavobacterium spp. 1 grown in Bushnell haas medium at different temperature.

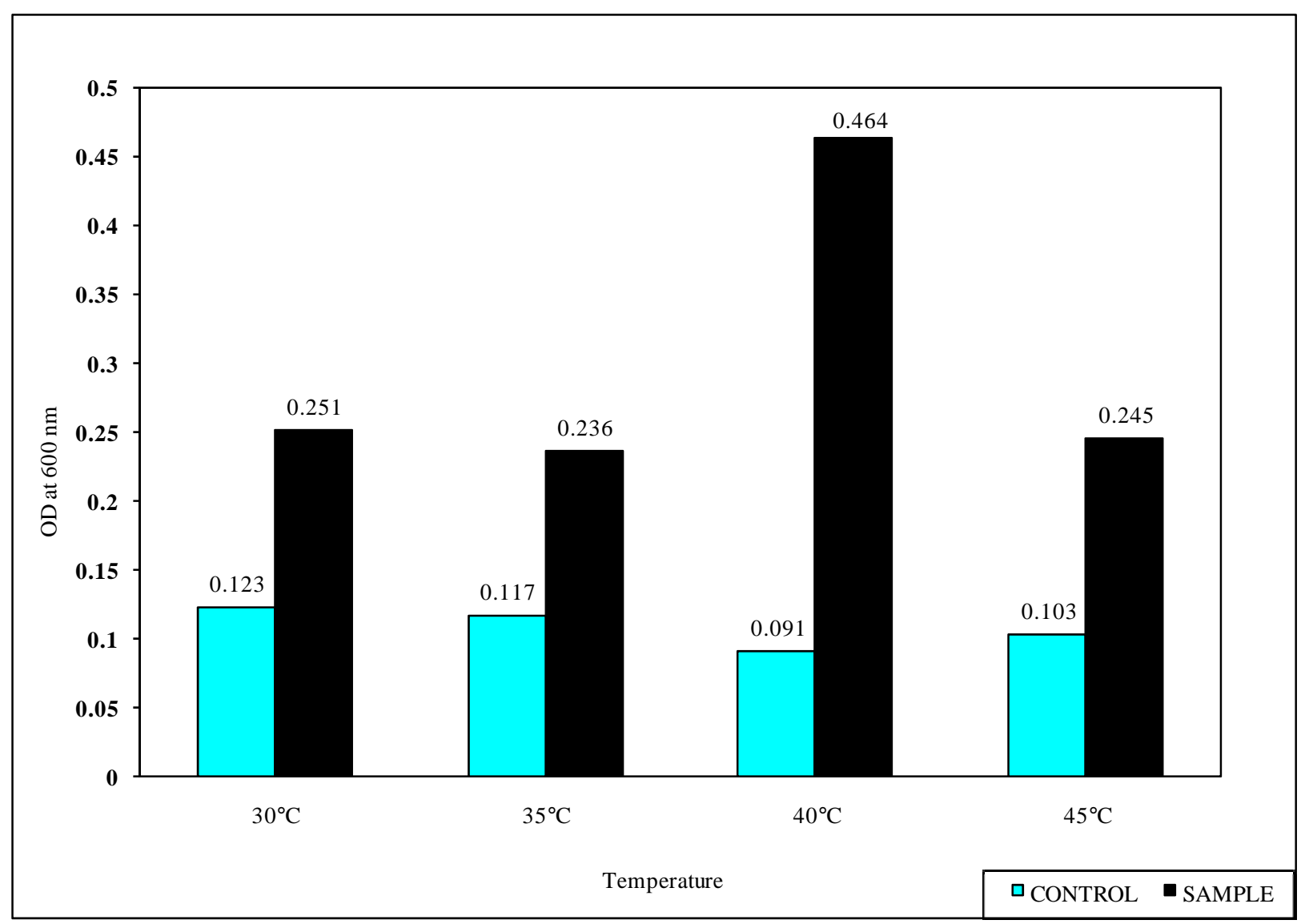

Figure 10. Average optical density of Flavobacterium spp. 2 grown in Bushnell haas medium at different temperature. 


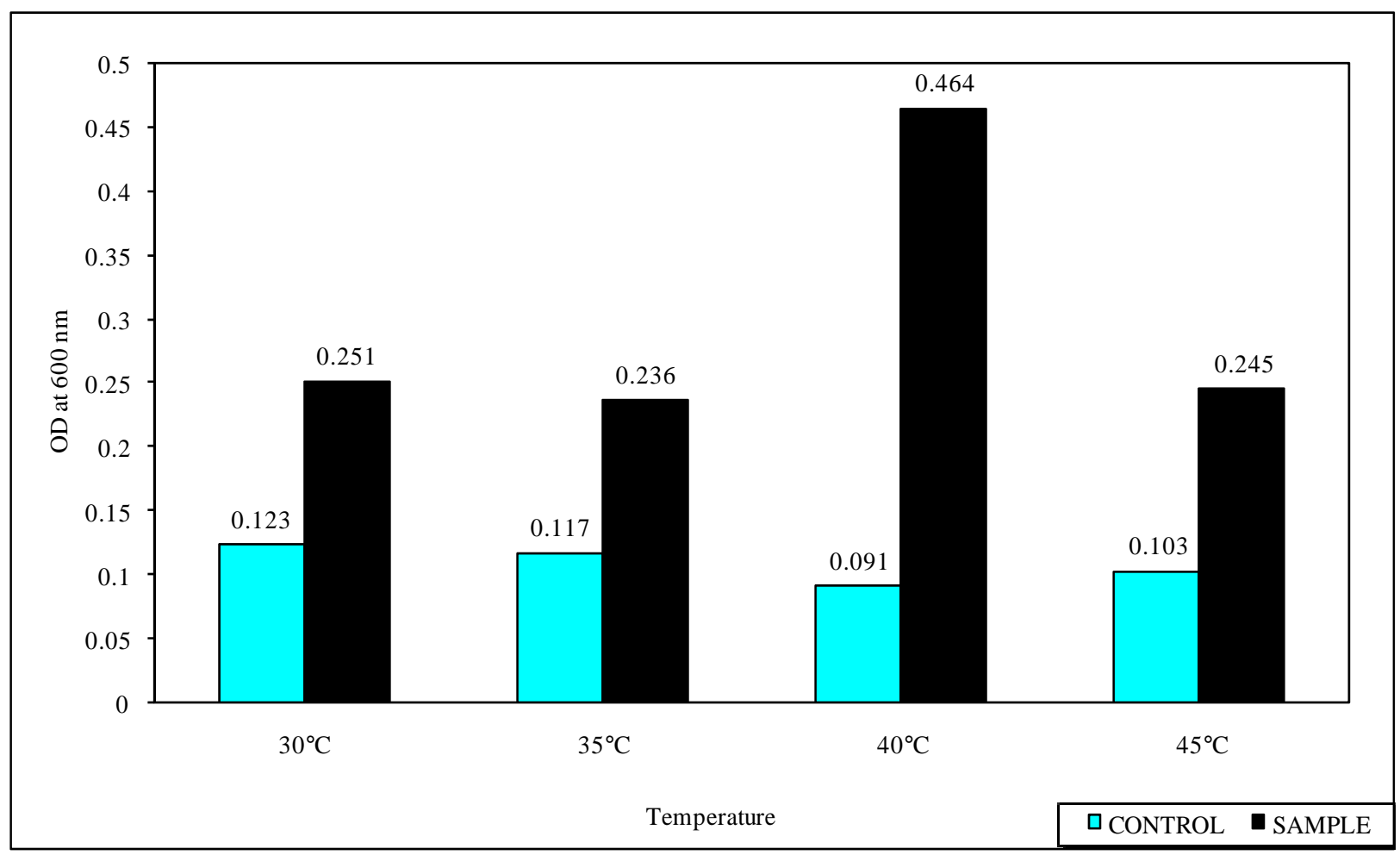

Figure 11. Average optical density of Pseudomonas spp.1 grown in Bushnell haas medium at different temperature.

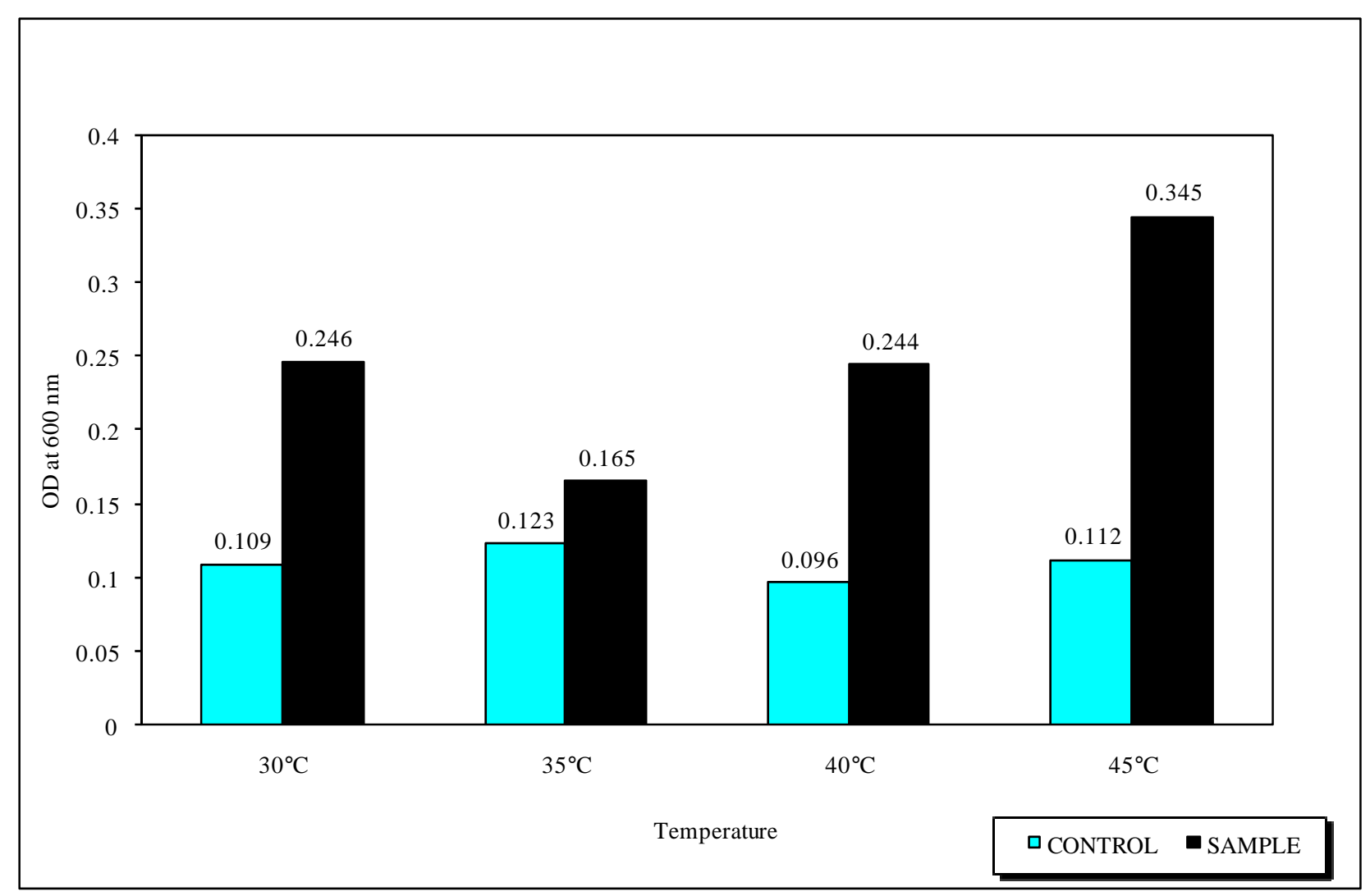

Figure 12. Average optical density of Pseudomonas spp.2 grown in Bushnell haas medium at different temperature. 
Table 1. Bio chemical characterization of bacterial isolates from oil contaminated sites.

\begin{tabular}{|c|c|c|c|c|c|}
\hline \multirow{2}{*}{ S.No } & \multirow{2}{*}{ Cultural Characteristics } & \multicolumn{4}{|c|}{ Bacterial Isolates } \\
\hline & & Flavo bacterium spp.1 & Flavo bacterium spp. 2 & Pseudomonas spp.1 & Pseudomonas spp.2 \\
\hline 1. & Colony Morphology & $\begin{array}{l}\text { Rhizoid Yellow } \\
\text { pigented colonies. }\end{array}$ & $\begin{array}{c}\text { Rhizoid Yellow } \\
\text { pigmented colonies. }\end{array}$ & $\begin{array}{c}\text { Small, Pigmented } \\
\text { Circular, Flat, Entire, } \\
\text { dry colonies }\end{array}$ & $\begin{array}{c}\text { Small, Pigmented } \\
\text { Circular, Flat, Entire, } \\
\text { dry colonies }\end{array}$ \\
\hline 2. & Gram's Staining & Gram negative & Gram negative & Gram negative & Gram negative \\
\hline 3. & Motility & Gliding Motility & Gliding Motility & Active Motile & Active Motile \\
\hline 4. & Catalase & + & + & + & + \\
\hline 5. & Oxidase & + & + & - & + \\
\hline 6. & Indole & + & + & - & + \\
\hline 7. & Methyl red & - & - & - & - \\
\hline 8. & VP Test & - & - & - & - \\
\hline 9. & Citrate Test & - & - & - & + \\
\hline 10. & Nitrate Test & - & - & - & + \\
\hline 11. & H2S production & + & + & + & + \\
\hline
\end{tabular}

Table 2. Heavy metal tolerance spectrum of hydrocarbon degrading bacteria,

\begin{tabular}{|c|c|c|c|c|c|}
\hline Heavy Metals & $\begin{array}{l}\begin{array}{c}\text { Concentration } \\
(\mu \mathrm{g} / \mathrm{ml})\end{array} \\
\end{array}$ & Flavo bacterium spp. 1 & Flavo bacterium spp. 2 & Pseudomonas spp.1 & Pseudomonas spp. 2 \\
\hline & 1 & - & - & - & - \\
\hline \multirow[t]{3}{*}{$\begin{array}{l}\text { Cobalt (Cobalt } \\
\text { Chloride) }\end{array}$} & 3 & - & - & - & - \\
\hline & 5 & - & - & - & - \\
\hline & 1 & + & + & + & + \\
\hline \multirow[t]{3}{*}{$\begin{array}{c}\text { Iron } \\
\text { (Ferrous Sulphate) }\end{array}$} & 3 & + & + & + & + \\
\hline & 5 & + & + & + & + \\
\hline & 1 & - & - & - & - \\
\hline \multirow[t]{3}{*}{$\begin{array}{l}\text { Mercury (Mercury } \\
\text { Sulphate) }\end{array}$} & 3 & - & - & - & - \\
\hline & 5 & - & - & - & - \\
\hline & 1 & + & + & + & + \\
\hline \multirow[t]{3}{*}{$\begin{array}{l}\text { Lead (Lead } \\
\text { Acetate) }\end{array}$} & 3 & + & + & + & + \\
\hline & 5 & + & + & + & + \\
\hline & 1 & + & + & + & + \\
\hline \multirow[t]{2}{*}{$\begin{array}{l}\text { Zinc (Zinc } \\
\text { Sulphate) }\end{array}$} & 3 & + & + & + & + \\
\hline & 5 & + & + & + & + \\
\hline
\end{tabular}


Table 3. The protein content of hydrocarbon degrading bacteria.

\begin{tabular}{cccc}
\hline Isolates & & Protein Content mg/100 ml \\
\hline Flavo bacterium spp. 1 & Control & Sample(X) & 1.7 \\
& Flavo bacterium spp. 2 & Control & 1.8 \\
& Sample(X) & 1.5 & 1.7 \\
Pseudomonas spp. 1 & Control & Sample (T) & 1.7 \\
& Control & 1.7 & 1.6 \\
Pseudomonas spp.2 & Sample (T) & 1.4 \\
\hline
\end{tabular}

X ------------ Xylene T ------------ Toluene

\section{Conclusions}

Hydrocarbon degrading bacteria from oil-contaminated site have utilized aromatic hydrocarbons at wide range of temperature and $\mathrm{pH}$. Therefore, Flavobacterium spp and Pseudomonas spp are recommended for bioremediating oil contaminated sites.

\section{Acknowledgements}

The authors are thankful to the Management Vael's Educational Trust, Pallavaram, Chennai, India for providing all the facilities to carry out this research work.

\section{REFERENCES}

[1] G. Mastrangela, E. Fadda and V. Marzia, "Polycyclic Aromatic Hydrocarbons and Cancer in Man," Environment Health Perspect, Vol. 104, No. 11, 1997, pp. 11661170. doi:10.1289/ehp.961041166

[2] M. Blumer, "Polycyclic Aromatic Hydrocarbons in Nature,” Scientific Americian, Vol. 234, No. 1, 1976, pp. 34-44. doi:10.1038/scientificamerican0376-34

[3] M. Bossert, W. Kachel and R. Bartha, "Fate of Hydrocarbons during Oily Sludge Disposal in Soil," Applied Environment Microbiology, Vol. 47, No. 4, 1984, pp. 763-767.

[4] L. A. Levin and V. A. Forchiassin, "Degradation of Organic Pollutants by the White Rot Basidiomycete Trametes Trogii," International Biodeterioration \& Biodegradation, Vol. 52, 2003, pp. 1-5. doi:10.1016/S0964-8305(02)00091-4

[5] M. F. Ghazali, N. R. Zakha, R. N. Abdul, A. B. Salleh and M. Basri, "Biodegradation of Hydrocarbons in Soil by Microbial Consortium,” International Biodeterioration and Biodegradation, Vol. 54, No. 1, 2004, pp. 61-67. doi:10.1016/j.ibiod.2004.02.002

[6] P. V. O. Trindada, L. G. Sobral, A. C. L. Rizzo, S. G. F. Leitic and A. U. Soriano, "Bioremediation of a Weathered and Recently Oil Contaminated Soils from Brazil-A Comparison Study,” Chemosphere, Vol. 58, No. 4, 2004, pp. 515-522. doi:10.1016/j.chemosphere.2004.09.021

[7] J. V. Pothuluri and C. E. Cerniglia, "Microbial Metabolism of Polycyclic Aromatic Hydrocarbons,” In: G. R. Chaudry, Ed., Biological Degradation and Bioremediation Toxic Chemicals, Chapman and Hall, London, 1994, pp. 92-124.

[8] J. G. Leahy, K. D. Tracy, M. H. Eley, "Degradation of Mixtures of Aromatic and Aliphatic Hydrocarbons by Aromatic Hydrocarbon-Degrading Bacteria," FEMS-Microbiology-Ecology, Vol. 43, No. 2, 2003, pp. 271-276. doi:10.1111/j.1574-6941.2003.tb01067.x

[9] R. Shakoori and B. Zahra, "Hydrocarbon Degrading Bacteria Isolated from Soil Samples and Industrial Effluents and Their Potential Use in Environmental Cleanup," Proceedings of Pakistan Congress of Zoology, Vol. 19, 1999, pp. 309-338.

[10] I. Nnamchi, A. N. Obeta and L. I. Ezeogu, "Isolation and Characterization of Polycyclic Aromatic Hydrocarbon Degrading Bacteria from Nsukka Soils in Nigeria," International Journal of Environmental Science and Technology, Vol. 3, No. 2, 2006, pp. 181-190.

[11] E. R. Roberts, "Bioremediation of Petroleum Contaminated Sites,” RC Press InC., Boca Raton, 1992.

[12] J. G. Bundy, G. I. Paton and C. D. Campbell, “Combined microbial Community Level and Single Species Biosensor Responses to Monitor Recovery of Oil Polluted Soil," Soil Biology and Biochemistry, Vol. 36, 2004, pp. 11491159. doi:10.1016/j.soilbio.2004.02.025

[13] T. Mandri and J. Lin, "Isolation and Characterization of Engine Oil Degrading Indigenous Micro Organisms in Kwazulu Natal, South Arica," African Journal of Biotechnology, Vol. 6, No. 1, 2007, pp. 23-27.

[14] S. J. Lu, H. Q. Wang and Z. H. Yao, "Isolation and Characterization of Gasoline Degrading Bacteria from Gas Station Leaking Contaminated Soil," Journal of Environmental Sciences, Vol. 8, 2006, pp. 969-972. doi:10.1016/S1001-0742(06)60023-5

[15] Sivapriya and R. Nirmala, "Biodegradation of Cyclohexonal by Bacteria Isolated from Oil Spilled Soil Around Vandavasi,” Journal of Ecotoxicology and Environmental Monitoring, Vol. 13, 2003, pp. 185-190. 
[16] J. G. Holt, “Bergy’s Manual of Determinative Bacteriology," 9th Edition, Williams and Wilkins, Philadelphia, 1994.

[17] G. Coral and S. Karagoz, "Isolation and Characterization of Phenanthrene Degrading Bacteria from Petroleum Refinery Soil," Annals of Microbiology, Vol. 55, No. 4, 2005, pp. 255-259.

[18] S. Y. Yuan, S. W. Chang, B. V. Chang, "Biodegradation of Polycyclic Aromatic Hydrocarbons in Sludge,” Bulletin of Environmental Contamination and Toxicology, Vol. 7, No. 3, 2003, pp. 625-632. doi:10.1007/s00128-003-8841-X
[19] N. Englert, G. Harms and F. Widdel, “Aerobic Petroleum Degradation Rate of Aromatic Hydrocarbon," Achieves of Microbiology, Vol.172, 1993, pp. 303-312.

[20] H. Feitkenhauer and H. Mark, "Biodegradation of Aliphatic and Aromatic Hydrocarbons at High Temperature,” Water Science and Technology, Vol. 47, No. 10, 2003, pp. 123-130.

[21] A. S. R. Ghosh and V. Singh, "Characterization of Large Plasmid Encoding Resistance to Toxic Heavy Metals in Salmonella Abortus Equi,” Biochemical and Biophysical Research Communications, Vol. 272, No. 1, 2000, pp. 6-11. doi:10.1006/bbrc.2000.2727 